
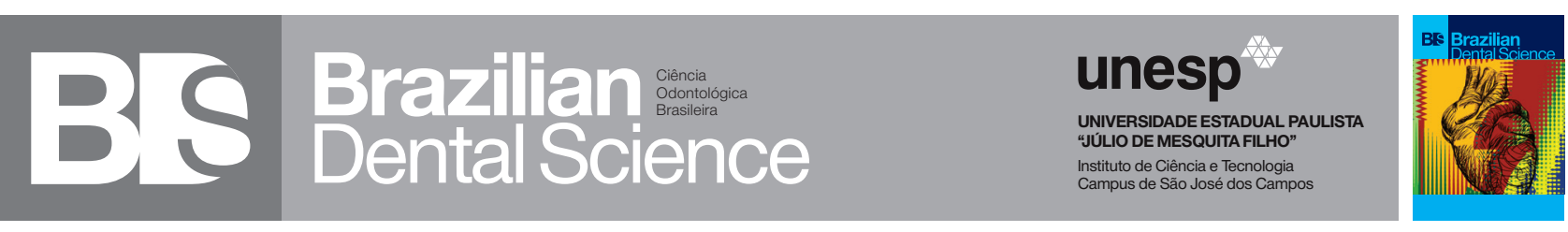

\title{
Comparative evaluation of postoperative pain intensity after single-visit and multiple-visit retreatment cases: a prospective randomized clinical trial
}

Avaliação comparativa da intensidade da dor pos-operatoria após casos de retratamento em sessao unica ou multipla: estudo clínico randomizado prospectivo

Hatice Miray UYAN ${ }^{1}$, Keziban OLCAY ${ }^{1}$, Mutlu ÖZCAN ${ }^{2}$

1 - Department of Endodontics - Faculty of Dentistry - Istanbul Medipol University - Istanbul - Turkey.

2 - Dental Materials Unit - Centre for Dental and Medicine - Clinic for fixed and Removable Prosthodontics and Dental Materials Science - University of Zurich -Zurich - Switzerland.

\begin{abstract}
Objectives: This study was designed to evaluate postoperative pain after endodontic retreatment. Material and Methods: Asymptomatic, multirooted molar \& premolar teeth requiring retreatment with $2-5 \mathrm{~mm}$ periapical lesions were included. Seventy-eight teeth were randomly placed in four groups $(n=20)$ : single-visit (control, group 1 ), Ledermix (group 2), metronidazole, ciprofloxacin, minocycline mixture (group 3), calcium hydroxide (group 4). The postoperative pain was recorded using a VAS at $6,12,24$, and $48 \mathrm{~h}$ after retreatment. Statistical evaluation was performed using TwoWay Repeated Measures ANOVA and Tukey test. Results: Mild pain occurred in $67.5 \%$, moderate in $30 \%$, and flare-ups in $2.5 \%$, and there was a significant difference between the groups $(\mathrm{p}<0.01)$. Significantly lower postoperative pain was observed in TAP and $\mathrm{CaOH} 2$ groups $(\mathrm{p}<0.05)$. In the 6,12 , and $24 \mathrm{~h}$ intervals, there was a significant difference in the pain levels $(p<0.05)$. Conclusion: TAP and $\mathrm{CaOH}_{2}$ are effective for reducing postoperative pain after retreatment.
\end{abstract}

\section{KEYWORDS}

Intracanal medicaments; Multiple-visit; Postoperative pain; Retreatment; Single-visit.

\begin{abstract}
RESUMO
Objetivo: Este estudo foi projetado para avaliar a dor pós-operatória após o retratamento endodôntico. Material e Métodos: Foram incluídos dentes molares e pré-molares multirradiculados e assintomáticos que necessitavam de retratamento com lesões periapicais de $2-5 \mathrm{~mm}$. Setenta e oito dentes foram distribuídos aleatoriamente em quatro grupos $(n=20)$ : sessão única (controle, grupo I), Ledermix (grupo II), metronidazol, ciprofloxacina, mistura de minociclina (grupo III), hidróxido de cálcio (grupo IV). A dor pósoperatória foi registrada usando um VAS às 6,12 , 24 e 48 h após o retratamento. A análise estatística foi realizada utilizando ANOVA de dois fatores para medidas repetidas e teste de Tukey. Resultados: Ocorreu dor leve em 67,5\%, moderada em 30\% e agudizações 2,5\%, e houve diferença significativa entre os grupos $(\mathrm{p}<0,01)$. Foi observada dor pósoperatória significativamente menor nos grupos TAP e hidróxido de cálcio $(\mathrm{p}<0,05)$. Nos intervalos de 6 , 12 e 24 h, houve diferença significativa nos níveis de dor ( $\mathrm{p}<0,05)$. Conclusão: TAP e hidróxido de cálcio são eficazes para reduzir a dor pós-operatória após o retratamento.
\end{abstract}

\section{PALAVRAS-CHAVE}

Medicamentos intracanais; Múltiplas sessões; Dor pós-operatória; Retratamento; Sessão única. 


\section{INTRODUCTION}

$\mathrm{P}$ ostoperative pain is defined as any pain that occurs after root canal therapy [1]. Endodontic pain has been the main motive for patient consultations following treatment, and it affects patient comfort. Complaints of postoperative pain range from 3-58\% of patients after root canal therapy [1]. It can be associated with inflammation in the periradicular tissues, and it is believed that the most important reason for endodontic treatment failure is microorganisms in the apical third of the root canal that survive after endodontic procedures [2]. The elimination of these microorganisms is very important for the success of endodontic therapy and reducing postoperative pain, especially in retreated infected root canals [3]. Thus, in addition to the antibacterial effects of the chemo-mechanical preparation and irrigation procedures, intracanal dressing has been recommended for long-lasting effects against the microorganisms in the root canal [4]. Calcium hydroxide $(\mathrm{CaOH} 2)$ has been used for this treatment for many years [4,5], and its many advantages, such as a high $\mathrm{pH}$, antibacterial effects, hard tissue stimulation, and reduced cytotoxicity to the periapical tissues, are the main reasons why it is so popular as an intracanal medicament [6]. Because of its high-pH and antibacterial activity, $\mathrm{CaOH}_{2}$ is still commonly used as a root canal dressing material in multiple-visit root canal treatments [7].

However, some studies have reported that using $\mathrm{CaOH}_{2}$ as intracanal medicament may weaken the mechanical properties of the tooth [7-9], and that its antibacterial capability is not quite strong enough, especially against Enterococcus faecalis and Candida albicans, the most important microorganisms cultured from the root canals of teeth in failed endodontic treatments [2]. Moreover, when the bacteria present in the dentinal tubules, tissue remnants, and anatomical variations are considered,
$\mathrm{CaOH} 2$ generally has difficulty reaching the microorganisms in these areas because of its low solubility and diffusibility [10]. There are some intracanal medicament alternatives to $\mathrm{CaOH} 2$; for example, Ledermix paste, containing both a corticosteroid and an antibiotic, has been suggested for use in dentistry for many years [11]. Its ability to relieve the postoperative pain associated with acute apical periodontitis [12], diffusion through the dentinal tubules, antiinflammatory characteristics, and broad-spectrum antimicrobial effectiveness against endodontic microorganisms [12] make Ledermix paste an attractive alternative for $\mathrm{CaOH} 2$. In recent years, a mixture including metronidazole, ciprofloxacin, and minocycline, also known as triple antibiotic paste (TAP), has become the most widely used intracanal medicament for regenerative endodontic procedures [13]. Metronidazole is a wide-spectrum bactericidal antibiotic [14], but increasing the concentration of metronidazole does not kill more of the bacteria. In order to sterilize the infected root canal, ciprofloxacin and minocycline are also needed [14].

Single versus multiple-visit root canal treatment is arguably a long-lasting topic in the endodontic community [1] with no definitive conclusion. The majority of the research to date has shown no significant difference when comparing single-visit and multiple-visit root canal treatments. To our knowledge, there is a need for a randomized clinical trial in retreatment cases; therefore, the present study was designed to compare the effects of singlevisit and multiple-visit root canal treatments on postoperative pain in retreatment cases. The primary outcome measure of this study was to assess whether different intracanal medicaments and single-visit root retreatment influenced the occurrence of postoperative pain. The null hypothesis was that there was no difference among the groups in the postoperative pain level. 


\section{MATERIALS AND METHODS}

This prospective randomized clinical trial involved 78 multi-rooted molar and premolar teeth belonging to 75 patients who had been referred for root canal retreatment to the Department of Endodontics, Faculty of Dentistry at Istanbul Medipol University in Turkey between March 2015 and July 2015. The sample size was calculated as 20 in each group, with 30\% effect sizes, a type I error of 0.05 , and a statistical power of $80 \%$ using the G*Power software (version 3.1.9.2). Based on the post hoc power analysis performed after the end of the study, this study was found to be reliable, with over $95 \%$ power and a middle size effect. The Ethics Committee of the Istanbul Medipol University approved both the protocol and informed consent document (No: 156). Before the retreatments, the nature of the study, complications, and associated risks were totally explained, and written informed consent was obtained from all of the study participants. Figure 1 shows the CONSORT flow diagram, and this clinical study is registered at www.clinicaltrials.gov (Registration ID: NCT03042377).

All of the retreatments were performed by the same specialist (H.M.U.), who has 10 years of experience. The most common reasons for tooth failure were insufficient restoration and/or root canal filling, coronal restoration missing for a long time, and prosthetic needs. The patients' ages ranged from 18 to 42 years old (mean 31.4). The patients were assigned to four medication groups randomly, with an equal allocation rate between the groups, and they were unaware of the study group to which they were allocated. The randomization protocol was performed via www.randomizer.org, which is a free resource for researchers to generate random numbers or assign participants to experimental conditions.

\section{ONSORT TRANSPARENT REPORTING of TRIALS}

CONSORT 2010 Flow Diagram

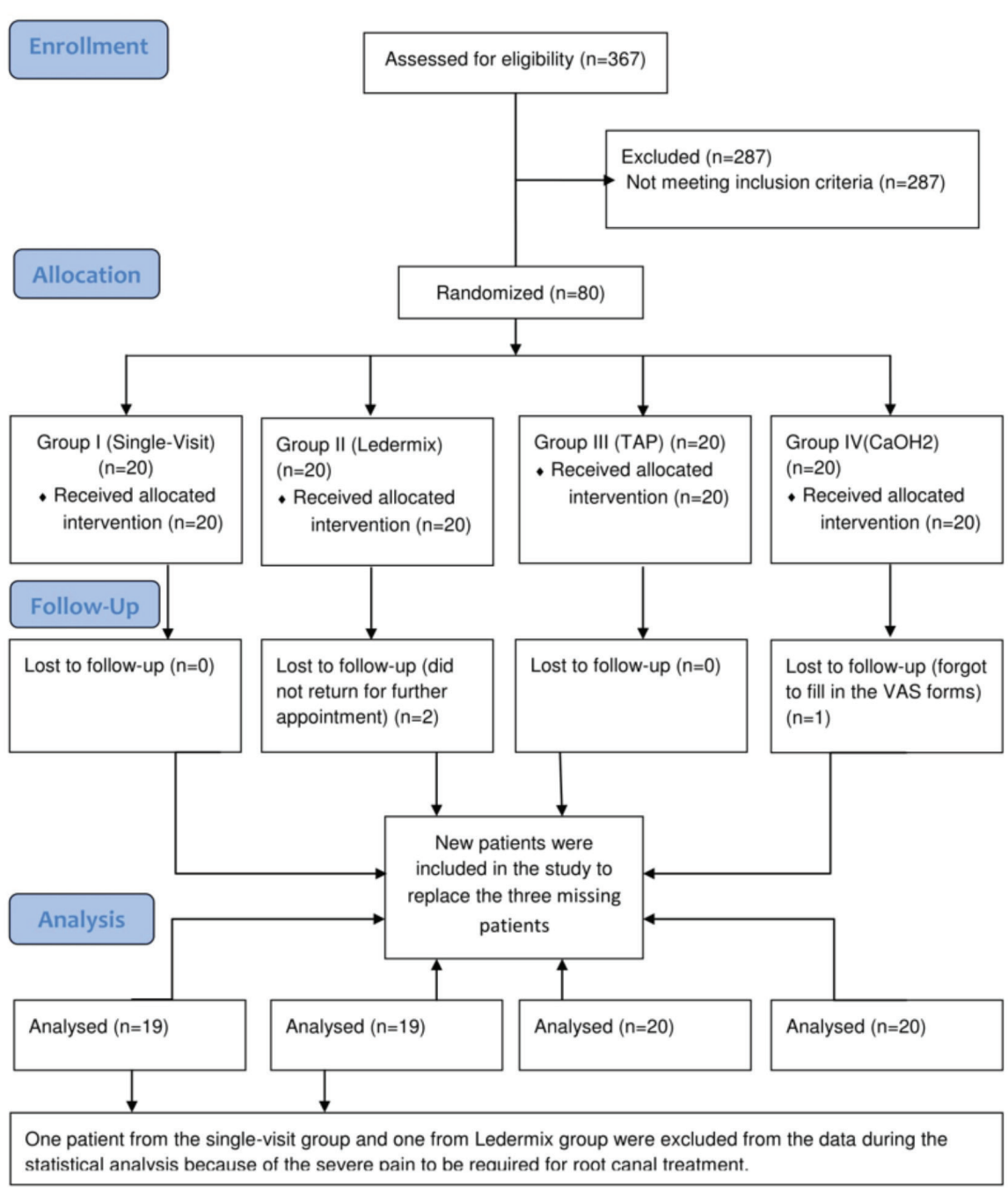

Figure 1 - CONSORT flow diagram for randomized clinical trials.

\section{Inclusion and Exclusion Criteria}

Only failed asymptomatic root-canal-treated permanent maxillary and mandibular multi-rooted teeth requiring retreatment, and having a periapical lesion diameter of $2-5 \mathrm{~mm}$, were included in this study. A patient was excluded for one of the following reasons: 
- Systemic disease

- Pregnant or breast feeding during the duration of the study

- Percussion/palpation pain and/or any facial swelling or abscess

- Immune-compromised

- Under 18 or over 65 years of age

- Took antibiotics or corticosteroids within the previous three months

- Known to be allergic to the ingredients of the materials used in this study

- Multiple teeth required retreatment in the same time period

- Eliminating pain referral

- Root canals that could not be treated well with orthograde retreatment

- Having tooth with open apex

Those patients who forgot to fill out the form were excluded from this study and patients who wanted to use analgesics were asked to record which medication they used, how many medications they took and the time they took medication.

\section{Retreatment Procedure}

The treatments in Group 1 were carried out in a single appointment and in Group 2, 3 and 4 were in multiple appointments. The standard procedure at the first appointment for all of the groups included local anesthesia with a standard inferior alveolar nerve block (IANB) for the mandibular molars and infiltrative anesthesia for the maxillary molars and premolar teeth. All of the anesthesia was administered using a 27 gauge, 2-inch dental needle (Set Inject; Set Medical Instruments, Istanbul, Turkey) with $1 \mathrm{ml}$ (for infiltrative) or $1.5 \mathrm{ml}$ (for IANB) of articaine and $0.012 \mathrm{mg} / \mathrm{ml}$ of epinephrine (Ultracaine D-S Forte; Aventis, Bridgewater, NJ, USA). Following anesthesia procedure, isolation provided with rubber-dam. If there were any crowns and/or fixed dental prosthesis removed initially to gain direct access to the relevant tooth. Caries and/ or coronal restorations were removed with sterile high-speed and low-speed burs, gaining access to the root canal system. Posts were primarily removed using an ultrasonic device (UDS-N2, Woodpecker, Guangxi, People's Republic of China) and if required with a portege. Then root canal fillings were removed by using a ProTaper Retreatment Kit (Dentsply Maillefer, Ballaigues, Switzerland) completely. No solvents were used to degrade the root canal filling or sealer.

After removing the entire root canal filling, the working length was determined with an apex locator (ProPex Pixi, Dentsply Maillefer, Ballaigues, Switzerland) with \#15 or \#20 Kerr files (Mani, Inc., Utsunomiya, Toghig1, Japan) depending on the post-treatment diameter of the root canal, $0.5 \mathrm{~mm}$ short of the apex. The working length was confirmed with a periapical radiograph. A master apical preparation was made in the narrow canals up to F3 and in the wide canals up to F5 using the ProTaper Universal Rotary System (Dentsply Maillefer, Ballaigues, Switzerland) in accordance to the manufacturer's instructions. During the retreatment procedures, apical patency was confirmed with \#15 Kerr file after each instrument, if needed. For lubrication in the root canal, RC-Plus (Medicept, Middlesex, UK) was used during the instrumentation. Throughout the retreatment, the root canal system irrigation was performed using 2.5\% sodium hypochlorite. Two milliliters of sodium hypochlorite were used to rinse the canals after each instrument using a disposable irrigation syringe (Endo-Eze; Ultradent Products $\mathrm{GmbH}$, Am Westhover Berg, Cologne, Germany). After the preparation was completed, each root canal was finally irrigated with $1 \mathrm{ml}$ of 17\% ethylenediaminetetraacetic acid (EDTA) to remove the smear layer. At the end of retreatment, the canals were irrigated with saline, dried with paper points, and treated with one of the medicaments indicated below: 
Group 1: Single-visit retreatment group (control)

Group 2: Ledermix paste (Medcare House, Gillingham, Kent, UK)

Group 3: A mixture of metronidazole, ciprofloxacin, and minocycline (Triple antibiotic paste, TAP)

Group 4: $\mathrm{CaOH}_{2}$ powder (Vision, Istanbul, Turkey) mixed with distilled water

In group 1 , following canal preparation, the root canals were obturated with AH Plus Sealer (Dentsply DeTrey GmbH, Konstanz, Germany) using a master cone of the same size as the apical file (ProTaper; Dentsply Maillefer) as a carrier. The lateral compaction was performed using size \#20 gutta percha cones (Dentsply Maillefer) with size \#25 nickel-titanium finger spreaders (Dentsply Maillefer). After cutting the gutta percha and cleaning the remnants from the cavity, an all-inone bond technique (Clearfil S3 Bond; Kuraray Noritake Dental Inc., Okayama, Japan) was used, according to the manufacturer's instructions, prior to the coronal restoration. Afterwards, the coronal restoration was completed using resin composite (Filtek ${ }^{\mathrm{TM}}$ Ultimate; 3M ESPE, St. Paul, MN, USA) and, if necessary, a fiber post (RelyX ${ }^{\mathrm{TM}}$ Fiber Post; 3M Deutschland GmbH Dental Products, Neuss, Germany).

The Ledermix paste that was used in Group 2 contained demeclocycline calcium equivalent to $30 \mathrm{mg}$ of demeclocycline hydrochloride and $10 \mathrm{~g}$ of triamcinolone acetonide in each gram of paste. The other ingredients were: calcium chloride, zinc oxide, anhydrous sodium sulfite (E221), trolamine, macrogol 3000, macrogol 400, sodium calcium edetate, colloidal anhydrous silica, and purified water.

In group 3 , the TAP contained equal volumes $(1: 1: 1)$ of metronidazole, ciprofloxacin, and minocycline. The paste for group 4 was prepared by mixing $\mathrm{CaOH}_{2}$ powder and distilled water until a creamy consistency was achieved.
All of the intracanal medications were inserted into the dried canals by using lentulo spirals (Mani Inc.) that were one size smaller than the last used file and $2 \mathrm{~mm}$ shorter than the working length, and packed with a cotton pellet at the level of the canal entrance. The access cavities were sealed (at a minimum of $3 \mathrm{~mm}$ in thickness) with temporary restorative filling material (Coltosol F; Coltene/Whaledent Inc., Altstatten, Switzerland). No antibiotics or analgesics were prescribed in any of the groups. The patients were also asked to stop taking analgesics and antibiotics, unless the pain persisted or recurred. If a patient needed to take medication, it was recorded.

\section{Postoperative Pain Evaluation}

At the end of retreatment, each patient was given an evaluation sheet, instructed about the treatment procedure and the use of a visual analogue scale (VAS) for pain, and told that it was to be returned during the following week (primary outcome). Each patient recorded their pain levels on a 170-mm Heft-Parker VAS [15] in well-defined categories at 4 time intervals: $6,12,24$, and 48 hours after treatment. The scale was divided into 4 categories (Table 1 ). No pain or faint pain corresponded to $0 \mathrm{~mm}$, while mild pain was defined as greater than $0 \mathrm{~mm}$ and less than or equal to $54 \mathrm{~mm}$. Mild pain included the descriptors of both weak and mild pain. Moderate pain was defined as greater than $54 \mathrm{~mm}$ and less than $144 \mathrm{~mm}$. Intense pain was defined as equal to or greater than $144 \mathrm{~mm}$, and included the descriptors of strong, severe, and maximum possible.

Seven days later, a further postoperative evaluation was performed at the second appointment. If the root was symptomatic, the root canal system was reopened, irrigated, dried, and medicated again. If it was asymptomatic, the root canal was irrigated, dried, and the treatment was completed as described above in Group 1. 
Table 1 - Categories of the Heft-Parker visual analog scale used for the assessment of postoperative pain

\begin{tabular}{ccc|} 
Categories & Pain values & Pain characteristics \\
\hline 1 & $0 \mathrm{~mm}$ & No pain; No pain \\
\hline 2 & $\leq 54 \mathrm{~mm}$ & $\begin{array}{c}\text { Mild pain; Weak or mild pain that does } \\
\text { not require analgesics }\end{array}$ \\
\hline 3 & $\begin{array}{c}>54 \mathrm{~mm},<144 \\
\mathrm{~mm}\end{array}$ & $\begin{array}{c}\text { Moderate pain; Pain that requires and is } \\
\text { relieved with analgesics }\end{array}$ \\
\hline 4 & $\geq 144 \mathrm{~mm}$ & $\begin{array}{c}\text { Intense pain; Strong, severe, and maxi- } \\
\text { mum possible pain not relieved by any } \\
\text { medicine }\end{array}$ \\
\hline
\end{tabular}

\section{Statistical Analysis}

The findings were recorded onto a Microsoft Excel (2003) spreadsheet (Microsoft Office, Redmond, CA) for statistical evaluation using SPSS version 17.0 (SPSS Inc., Chicago, IL, USA). The age and postoperative HeftParker VAS pain rates of the patients were summarized using the means and standard deviations. The comparisons between the intracanal medicaments and different time intervals were analyzed using the two-way repeated measures ANOVA. Tukey test as Post hoc tests were used to determine significant differences between the groups at the same time intervals. For all of the performed tests, the level for significance was $\mathrm{p} \leq 0.05$. One patient from the single-visit group and one from Ledermix group were excluded from the data during the statistical analysis because of the possibility of extreme data (severe pain, too much pain to require root canal treatment) affecting the reliability of the results.

\section{RESULTS}

A total of 78 teeth belonging to 75 patients were treated in this study. Of these, three patients (two from Group 2 and one from the Group 4) who did not return for further appointments and/or forgot to fill out the Heft-Parker VAS forms were excluded from this research. The baseline demographic and clinical characteristics of the patients in each group are shown in Table 2 .

Table 2 - Demographic and clinical characteristics of the patients in each of the study groups

\begin{tabular}{|c|c|c|c|c|}
\hline $\begin{array}{c}\text { Baseline } \\
\text { demographic } \\
\text { and clinical } \\
\text { characteristics }\end{array}$ & $\begin{array}{c}\text { Group1 } \\
\text { (single-vis- } \\
\text { it) }(n=19)\end{array}$ & $\begin{array}{l}\text { Group } \\
2 \text { (Le- } \\
\text { dermix) } \\
(n=19)\end{array}$ & $\begin{array}{l}\text { Group } \\
3(T A P) \\
(n=20)\end{array}$ & $\begin{array}{r}\text { Group } 4 \\
\left(\mathrm{CaOH}_{2}\right) \\
(\mathrm{n}=20)\end{array}$ \\
\hline Systemic disease & 0 & 0 & 0 & 0 \\
\hline Periapical lesions & 19 & 19 & 20 & 20 \\
\hline Preoperative pain & 0 & 0 & 0 & 0 \\
\hline $\begin{array}{l}\text { Preoperative } \\
\text { swelling }\end{array}$ & 19 & 19 & 20 & 20 \\
\hline $\begin{array}{l}\text { Preoperative } \\
\text { palpation and } \\
\text { percussion } \\
\text { sensitivity }\end{array}$ & 0 & 0 & 0 & 0 \\
\hline $\begin{array}{l}\text { Took preoperative } \\
\text { drugs }\end{array}$ & 0 & 0 & 0 & 0 \\
\hline $\begin{array}{l}\text { Required } \\
\text { postoperative } \\
\text { analgesics }\end{array}$ & 3 & 0 & 0 & 0 \\
\hline $\begin{array}{l}\text { Postoperative } \\
\text { swelling }\end{array}$ & 2 & 0 & 0 & 0 \\
\hline $\begin{array}{l}\text { Postoperative } \\
\text { palpation and } \\
\text { percussion } \\
\text { sensitivity }\end{array}$ & 2 & 0 & 0 & 0 \\
\hline $\begin{array}{l}\text { Unscheduled } \\
\text { appointments for } \\
\text { flare-ups }\end{array}$ & 2 & 0 & 0 & 0 \\
\hline Single session & 19 & 0 & 0 & 0 \\
\hline Multiple sessions & 0 & 19 & 20 & 20 \\
\hline
\end{tabular}

Of all the retreated teeth, only two (2.5\%) showed flare-ups (from Group 1), and only three patients, of whom two were from flare-up patients and one from others, took analgesics during the postoperative 48 hours (all from Group 1). The two flare-ups were designated as such based on severe pain and swelling. The data associated with the age, gender, and tooth type are summarized in Table 3. 
Table 3 - Distribution of data associated with age, gender, and tooth type

\begin{tabular}{|c|c|c|c|c|c|c|}
\hline $\begin{array}{l}\text { Baseline } \\
\text { demo- } \\
\text { graphic } \\
\text { charac- } \\
\text { teristics }\end{array}$ & $\begin{array}{l}\text { Sample } \\
\text { size }\end{array}$ & $\begin{array}{c}\text { Group } 1 \\
\text { (single- } \\
\text { visit) } \\
(n=19)\end{array}$ & $\begin{array}{l}\text { Group } \\
2 \text { (Le- } \\
\text { dermix) } \\
(n=19)\end{array}$ & $\begin{array}{l}\text { Group } \\
3(T A P) \\
(n=20)\end{array}$ & $\begin{array}{c}\text { Group } 4 \\
(\mathrm{CaOH}) \\
(\mathrm{n}=20)\end{array}$ & $\begin{array}{c}\mathrm{P} \text { - } \\
\text { value }\end{array}$ \\
\hline \multirow[b]{2}{*}{ Gender } & Male (\%) & $6(31.5)$ & $12(63)$ & $9(45)$ & $12(60)$ & $p>0.05$ \\
\hline & $\begin{array}{l}\text { Female } \\
(\%)\end{array}$ & $13(68.5)$ & $7(37)$ & $11(55)$ & $8(40)$ & 20 \\
\hline \multirow{2}{*}{ Age } & Mean & 31.10 & 32.65 & 31.05 & 30.40 & $p>0.05$ \\
\hline & Range & $20-41$ & $25-43$ & $18-45$ & $21-42$ & \\
\hline \multirow{2}{*}{$\begin{array}{l}\text { Tooth } \\
\text { type }\end{array}$} & Premolar & 9 & 5 & 6 & 8 & $p>0.05$ \\
\hline & Molar & 10 & 14 & 14 & 12 & \\
\hline
\end{tabular}

TAP: triple antibiotic paste including metronidazole, ciprofloxacin, and minocycline.

The distribution of the postoperative pain values for each treatment group by each time period is summarized in Table 4. A significant difference was found between the tested groups in all of the time periods $(p<0.01)$. The mean postoperative pain score for all of the groups in all of the time periods was 49.4, ranging from $19.7\left(\mathrm{CaOH}_{2}\right.$ group, $6 \mathrm{~h}$ ) to 79.1 (single-visit group, $48 \mathrm{~h}$ ). Mild pain occurred in $67.5 \%$ of the patients, moderate in $30 \%$, and flare-ups in $2.5 \%$. No differences were found between the groups with regard to the following preoperative conditions: age ( $p>0.05)$, gender $(p>0.05)$, swelling, sensitivity to percussion and palpation, preoperative pain, preoperative coronal restoration, and preoperative analgesics and antibiotics taken ( $\mathrm{p}>0.05)$.

Table 4 - Distribution of postoperative pain values according to treatment group

\begin{tabular}{|c|c|c|c|}
\hline $\begin{array}{l}\text { Time intervals } \\
\text { Retreated } \\
\text { groups }\end{array}$ & $12 \mathrm{~h}$ & $48 h$ & $\begin{array}{c}\text { P- } \\
\text { value }\end{array}$ \\
\hline $\begin{array}{c}\text { Group1 } \\
\text { (single-visit) }\end{array}$ & $52.61 \pm 3.43^{a} \quad 61.44 \pm 3.89^{b}$ & $69.34 \pm 3.85^{\mathrm{bc}} 76.74 \pm 3.45^{\mathrm{bc}}$ & $p<0.05$ \\
\hline $\begin{array}{c}\text { Group } 2 \\
\text { (Ledermix) }\end{array}$ & $54.89 \pm 3.31^{\mathrm{a}} 64.27 \pm 3.74^{\mathrm{a}}$ & $61.77 \pm 3.71^{\mathrm{a}} \quad 44.32 \pm 3.32^{\mathrm{b}}$ & $p<0.05$ \\
\hline $\begin{array}{l}\text { Group } 3 \\
\text { (TAP) }\end{array}$ & $24.44 \pm 3.13^{\mathrm{a}} 40.15 \pm 3.54^{\mathrm{ac}}$ & $44.95 \pm 3.51^{\mathrm{ac}} \quad 36.82 \pm 3.14^{\mathrm{ac}}$ & $p<0.05$ \\
\hline $\begin{array}{c}\text { Group } 4 \\
(\mathrm{CaOH} 2)\end{array}$ & $19.77 \pm 3.18^{a} \quad 28.38 \pm 3.59^{b}$ & $36.92 \pm 3.56^{b} \quad 38.75 \pm 3.19^{b}$ & $p<0.05$ \\
\hline $\begin{array}{l}\text { TAP: triple } \\
\text { ciprofloxacin, } \\
\text { Different supe }\end{array}$ & $\begin{array}{l}\text { antibiotic paste } \\
\text { and minocycline. Not } \\
\text { erscript letters in the s }\end{array}$ & $\begin{array}{l}\text { including metronic } \\
\text { tes: Cell values are mea } \\
\text { same line indicate stati }\end{array}$ & idazole, \\
\hline
\end{tabular}

There was a significant difference between the groups $(p<0.01)$, with significantly lower postoperative pain observed in the TAP group $(\mathrm{p}<0.01)$ and $\mathrm{CaOH} 2$ group $(\mathrm{p}<0.01)$ than in the control (single-visit) and Ledermix groups. However, no difference was found between the TAP and $\mathrm{CaOH} 2$ groups $(\mathrm{p}>0.05)$. At the 6 , 12 , and $24 \mathrm{~h}$ intervals, there was a significant difference in the pain levels $(p<0.05)$, but at the $48 \mathrm{~h}$ interval there was no significant difference found between the groups ( $p>0.05$ ). The incidence of postoperative pain in the control (single-visit) and Ledermix groups was significantly higher than in the other groups $(\mathrm{p}<0.01)$, but no significant difference was found between the control (single-visit) and Ledermix groups.

In summary, the results of the 78 cases studied in all of the groups revealed that none of the patients were in the "no pain" category. Mild pain occurred in $67.5 \%$, moderate in $30 \%$, and the overall incidence of flare-ups was relatively low at $2.5 \%$ of the cases in all of the groups.

\section{DISCUSSION}

The aim of this clinical study was to compare the influence of different intracanal medicaments and single-visit root canal treatments on postoperative pain after retreatment cases. The Heft-Parker VAS scale, which is both valid and reliable for measuring pain, was used to determine the intensity of the postoperative pain [16]. The VAS scale was designed to be based on the patient's subjective judgment and relative experience. In this study, the level of pain was classified into four categories that were carefully identified as increasing the need for relief with analgesic use. This categorization made it easier for the patients to determine the level and allowed a more reliable pain rating. 
Root canal treatment should be based on antimicrobial applications to control the root canal infection. The microbial etiology of the periradicular tissues is probably the most common cause of flare-ups [17], especially in retreatment cases [3]. Since endodontic infections are polymicrobial, the teeth requiring endodontic retreatment may have a number of microorganisms related to the quality of the initial endodontic treatment and the length of the filling material [18]. It has also been reported in previous studies that the use of mechanical instrumentation alone in endodontic retreatment was not sufficient to completely eliminate the microorganisms $[2,3]$.

Even though some researchers have not supported this idea $[19,20]$, using an antimicrobial intracanal dressing is a valuable method for eliminating any remaining bacteria after root canal preparation. This reduces the inflammation of the periapical tissues and acts as a barrier against leakage from a temporary filling. Therefore, an antimicrobial intracanal dressing helps reduce postoperative pain and flare-ups [21]. $\mathrm{CaOH}_{2}$ is still a commonly used root canal dressing material for multiple-visit root canal treatments $[3,4,7]$ because of its high-alkalinity antibacterial activity and its ability to create an appropriate environment for hard tissue deposition and apical repair.

However, there are some disadvantages of using $\mathrm{CaOH} 2$, such as failing to completely eliminate Enterococcus faecalis in the dentinal tubules and Candida spp. that were found to be resistant to $\mathrm{CaOH}_{2}$ [22]. Therefore, we decided to use alternative intracanal medicaments in our study (Ledermix and TAP). Ledermix was reported an effective intracanal medicament for the control of postoperative pain associated with acute apical periodontitis [23]. TAP may also be a good alternative intracanal medicament with regard to its antibacterial activities. However, in recent years, the single-visit root canal retreatment has started to become popular [24] because of excessive request of patients such as; inadequate time, difficulty with negotiation, difficulty to continue to other dental visits etc. Some published studies reporting single-visit retreatments to be as successful as multiple visits and showing no difference in treatment complications $[24,25]$.

Regarding flare-ups, previous studies have reported different percentages ranging from 1.4\% to $16 \%[1,3,17,21,26,27]$ with retreatment cases especially reporting a higher incidence of flare-ups $[3,27]$. In the present study, the overall incidence of flare-ups was relatively low at $2.5 \%$, which is close to the lowest values reported by previous studies. This low rate of flare-ups may be related to the fact that the teeth in the present study were asymptomatic and had periapical lesion diameters of $2-5 \mathrm{~mm}$ (not the larger ones). Walton and Fouad [28] found no significant difference in the flare-up incidence between the treatment and retreatment cases, and reported that the incidence of flare-ups was $3.17 \%$. However, one systematic review reported that the odds ratio of flare-ups occurring in single-visit root canal treatments was 4.9 times that of multiple-visit treatments [1]. In the present study, all of the flare-ups were seen in the single-visit retreatment group and three patients, of whom two from flare-up patients, used one non-steroidal anti-inflammatory analgesic per person in 48 hours after the treatment. In addition, one patient from the single-visit group and one from Ledermix group were contained severe pain to require root canal therapy. The data from these two patients excluded from the all data during the statistical analysis to avoid the risk of the analysis being compromised.

Very low incidence rates of postoperative pain (aslow as 10\%) have been reported previously after single-visit root canal treatment [29], which may be due to assigning mild pain cases to the no pain category. Contrarily, the weak or none to slight pain cases were assigned to the mild pain category and the no pain category was defined as "none pain" in the present study. Furthermore, a systematic review of the frequency of persistent 
tooth pain after root canal therapy reported that the frequency of pain in retreatment studies was $6.6 \%$, on average, ranging from $3.4 \%$ to $9.9 \%$ [30]. In examining the present results, the pain intensity was reported to be mild in $67.5 \%$, moderate in $30 \%$, and severe in $2.5 \%$, when the average of all of the time intervals was considered for all of the groups.

In the current study, for the single-visit retreatment group, severe pain was found in 10\% of the cases, moderate in $70 \%$, and mild in $20 \%$ of twenty cases. This was relatively similar to the results of postoperative pain after applying five-hundred single-visit root canal treatments, reporting intense in $9.6 \%$ of the cases, moderate in $45.8 \%$, and mild in 43.5\% [31]. However, in Arias et al.'s study [31], the cases included single-visit root canal treatments, not retreatments, so it is difficult to compare their results with those of our study. In contrast, Yoldas et al. [3] investigated two-hundred and eighteen single-visit and multiple-visit retreatment cases and reported "none pain" in 73.9\%, mild pain in $17.8 \%$, moderate pain in $2.7 \%$, and severe pain in $5.4 \%$ of the single-visit asymptomatic group. In another study [17], the authors investigated 627 teeth with necrotic pulps or that required retreatment and reported mild pain in $10 \%$, moderate in $3.3 \%$, and severe in $1.9 \%$. However, determining the cause of the differences between the results of these studies is difficult. They may be related to the differences in the study design, periapical status of the treated teeth, or microbial diversity of the root canal infections.

The TAP and $\mathrm{CaOH}_{2}$ groups showed significantly lower incidences of postoperative pain than the single-visit group in this study. There have been some studies discussing the relationship between intracanal medicaments for postoperative pain in endodontics $[4,17,19$ $21,23]$ and the incidence of pain after endodontic treatments being performed in single or multiple visits $[1,29,32]$, but these studies were not about retreatment. Therefore, it would not be accurate to compare the results. The low incidence of pain in the TAP and $\mathrm{CaOH} 2$ groups probably indicates that these intracanal medicaments were significantly effective for eliminating the microorganisms in the root canal, and that they reduced the postoperative pain and flare-ups. Clinically, in retreatment cases, the use of an effective intracanal medicament between sessions is preferred.

\section{CONCLUSIONS}

The present findings revealed that using an antimicrobial intracanal dressing remains a recommended method for eliminating postoperative pain after retreatment cases. With regard to the clinical significance, the use of TAP and $\mathrm{CaOH} 2$ is effective for reducing postoperative pain after asymptomatic retreatment cases. Further studies must investigate postoperative pain relief in retreatment cases with larger periapical lesions and preoperative pain.

\section{COMPLIANCE WITH ETHICAL STANDARDS}

\section{Conflict of Interest}

The authors declare that they have no conflicts of interest with regard to this research.

\section{Funding}

This work was not supported by any funding source.

\section{Ethical Approval}

All of the procedures performed in this study involving human participants were in accordance with the ethical standards of the institutional and/or national research committee and with the 1964 Helsinki Declaration and its later amendments or comparable ethical standards.

\section{Informed Consent}

Each of the individual participants was informed and provided consent for their inclusion in this study. 


\section{ACKNOWLEDGMENTS}

This study was performed in the Medipol International Health Center of Medipol University Hospital. The authors thank Dr Pakize Yigit for statistical analysis. The authors report no conflicts of interest.

\section{REFERENCES}

1. Sathorn C, Parashos P,Messer H. The prevalence of postoperative pain and flare-up in single- and multiple-visit endodontic treatment: a systematic review. Int Endod J. 2008 Feb;41(2):91-9.

2. Siqueira JF Jr, Rôças IN. Clinical Implications and microbiology of bacterial persistence after treatment procedures. J Endod. 2008 Nov;34(11):1291-1301 e3. doi: 10.1016/j.joen.2008.07.028.

3. Yoldas 0 , Topuz A, Isçi AS, Oztunc H. Postoperative pain after endodontic retreatment: single versus two-visit treatment. Oral Surg Oral Med Oral Pathol Oral Radiol Endod. 2004 0ct;98(4):483-7.

4. Singh RD, Khatter R, Bal RK, Bal CS. Intracanal medications versus placebo in reducing postoperative endodontic pain--a double-blind randomized clinical trial. Braz Dent J. 2013;24(1):25-9.

5. Sjögren U, Figdor D, Spångberg L, Sundqvist G. The antimicrobial effect of calcium hydroxide as a short-term intracanal dressing. Int Endod J. 1991 May;24(3):119-25.

6. Zmener 0 , Pameijer CH, Banegas G. An in vitro study of the $\mathrm{pH}$ of three calcium hydroxide dressing materials. Dent Traumatol. 2007 Feb;23(1):21-5.

7. Batur YB, Erdemir U, Sancakli HS. The long-term effect of calcium hydroxide application on dentin fracture strength of endodontically treated teeth. Dent Traumatol. 2013 Dec;29(6):461-4.

8. Andreasen JO, Farik B, Munksgaard EC. Long-term calcium hydroxide as a root canal dressing may increase risk of root fracture. Dent Traumatol. 2002 Jun;18(3):134-7.

9. Doyon GE, Dumsha T, von Fraunhofer JA. Fracture resistance of human root dentin exposed to intracanal calcium hydroxide. J Endod. 2005 Dec;31(12):895-7.

10. Siqueira JF Jr, Magalhães KM, Rôças IN. Bacterial reduction in infected root canals treated with $2.5 \% \mathrm{NaOCl}$ as an irrigant and calcium hydroxide/ camphorated paramonochlorophenol paste as an intracanal dressing. J Endod. 2007 Jun;33(6):667-72.

11. Schroeder A. Corticosteroids in endodontics. J Oral Ther Pharmacol. 1965 Nov;2(3):171-9.

12. Bryson EC, Levin L, Banchs F, Abbott PV, Trope M. Effect of immediate intracanal placement of Ledermix Paste on healing of replanted dog teeth after extended dry times. Dent Traumatol. 2002 Dec;18(6):316-21.

13. Banchs F, Trope M. Revascularization of immature permanent teeth with apical periodontitis: new treatment protocol? J Endod. 2004 Apr;30(4):196200.

14. Mozayeni MA, Haeri A, Dianat O, Jafari AR. Antimicrobial effects of four intracanal medicaments on enterococcus faecalis: an in vitro study. Iran Endod J. 2014 Summer;9(3):195-8.
15. Heft MW, Parker SR. An experimental basis for revising the graphic rating scale for pain. Pain. 1984 Jun;19(2):153-61.

16. Price DD, McGrath PA, Rafii A, Buckingham B. The validation of visual analogue scales as ratio scale measures for chronic and experimental pain. Pain. 1983 Sep;17(1):45-56.

17. Siqueira JF Jr, Rôças IN, Favieri A, Machado AG, Gahyva SM, Oliveira JC, et al. Incidence of postoperative pain after intracanal procedures based on an antimicrobial strategy. J Endod. 2002 Jun;28(6):457-60.

18. Sundqvist G, Figdor D, Persson S, Sjögren U. Microbiologic analysis of teeth with failed endodontic treatment and the outcome of conservative re-treatment. Oral Surg Oral Med Oral Pathol Oral Radiol Endod. 1998 Jan;85(1):86-93.

19. Walton RE, Holton IF Jr, Michelich R. Calcium hydroxide as an intracanal medication: effect on posttreatment pain. J Endod. 20030ct;29(10):627-9.

20. Trope M. Relationship of intracanal medicaments to endodontic flare-ups. Endod Dent Traumatol. 1990 0ct;6(5):226-9.

21. Gama TG, de Oliveira JC, Abad EC, Rôças IN, Siqueira JF Jr. Postoperative pain following the use of two different intracanal medications. Clin Oral Investig.2008 Dec;12(4):325-30. do: 10.1007/s00784-008-0199-3.

22. Waltimo TM, Sirén EK, Orstavik D, Haapasalo MP. Susceptibility of oral Candida species to calcium hydroxide in vitro. Int Endod J. 1999 Mar;32(2):94-8.

23. Ehrmann EH, Messer HH, Adams GG. The relationship of intracanal medicaments to postoperative pain in endodontics. Int Endod J. 2003 Dec;36(12):868-75.

24. Eyuboglu TF, Olcay K, Özcan M. A clinical study on single-visit root canal retreatments on consecutive 173 patients: frequency of periapical complications and clinical success rate. Clin Oral Investig. 2017 Jun;21(5):1761-8.

25. Ashraf H, Milani AS, Shakeri Asadi S. Evaluation of the success rate of nonsurgical single visit retreatment. Iran Endod J. 2007 Summer;2(2):69-72.

26. Pamboo J, Hans MK, Kumaraswamy BN, Chander S, Bhaskaran S. Incidence and factors associated with flare-ups in a post graduate programme in the indian population. J Clin Exp Dent. 2014 Dec 1;6(5):e514-9.

27. Imura N, Zuolo ML. Factors associated with endodontic flare-ups: a prospective study. Int Endod J. 1995 Sep;28(5):261-5.

28. Walton R, Fouad A. Endodontic interappointment flare-ups: a prospective study of incidence and related factors. J Endod. 1992 Apr;18(4):172-7.

29. Fox J, Atkinson JS, Dinin AP, Greenfield E, Hechtman E, Reeman CA, et al. Incidence of pain following one-visit endodontic treatment. Oral Surg Oral Med Oral Pathol. 1970 Jul;30(1):123-30.

30. Nixdorf DR, Moana-Filho EJ, Law AS, McGuire LA, Hodges JS, John MT. Frequency of persistent tooth pain after root canal therapy: a systematic review and meta-analysis. J Endod. 2010 Sep;36(9):1494-8.

31. Arias A, de la Macorra JC, Hidalgo JJ, Azabal M. Predictive models of pain following root canal treatment: a prospective clinical study. Int Endod J. 2013 Aug;46(8):784-93. doi: 10.1111/iej.12059.

32. Patil AA, Joshi SB, Bhagwat SV, Patil SA. Incidence of Postoperative Pain after Single Visit and Two Visit Root Canal Therapy: A Randomized Controlled Trial. J Clin Diagn Res. 2016 May;10(5):ZC09-12. doi:10.7860/ JCDR/2016/16465.7724. Epub 2016 May 1. 


\section{Dr. Keziban Olcay}

\section{(Corresponding address)}

Atatürk Bulvarı, No: 27 Department of Endodontics,

Faculty of Dentistry, Istanbul Medipol University,

Unkapanı, Fatih, Istanbul.

E-mail: kolcay@medipol.edu.tr

Phone: +90 0212453 4800-4918

Date submitted: 2018 Nov 21

Fax: +9002125210426 